\title{
Mosquito species diversity and abundance in relation to riceland agroecosystem and filarial infection in Kafr El-Sheikh Governorate, Egypt.
}

\author{
*TAREK M.Y. EL-SHEIKH,${ }^{*}$ KOTB M. HAMMAD AND **WALAA A. MOSELHI \\ *Department of Zoology, Faculty of Science, Al-Azhar University, \\ **Department of Zoology, Faculty of Science (girls), Al-Azhar University.
}

\begin{abstract}
The present work studied the mosquitoes abundance, identification, distribution and density in three villages (rural area) and one city (urban area) in Kafr El-Sheikh Governorate namely; Kebreet, Minyat Al-Ashraaf, El-Salmia and Fowa city, respectively during the rice cultivation season in relation to filaria from June to Oct. 2009. A total of 11381 mosquitoes larvae belonging to four genera and 8 species were collected. Of which 3525 (31.0\%) in Minyat Al-Ashraaf followed by 3339 (29.3\%) in Kebreet, 3331 (29.3\%) in El-Salmia villages compared with $1186(10.4 \%)$ in Fowa city. The five most common species collected during this study were Culex pipiens (39.2\%), Cx. antennatus (27.3\%), Cx. univittatus (15.8\%), Anopheles pharoensis (10.4\%), and An. coustani (3.8\%). The mosquito species diversity $(H)$ and evenness $(E H)$ in the (rice cultivated areas) Minyat Al-Ashraf, Kebreet and El-Salmia villages $(H=$ $1.286, E H=0.829 ; H=1.227, E H=0.742 ; H=1.110, E H=0.882$; respectively) were much higher than in the Fowa city (non rice cultivated area) $(H=0.718, E H=0.608)$. On the other hand, the highest diversity and density of adult mosquitoes species obtained from Minyat AlAshraaf were 5 species and (33.8\%), followed by Kebreet 5 species and (31.6\%), El-Salmia 4 species and (24.5\%), respectively compared with 3 species and (10.1\%) in Fowa city. C. pipiens adults were the predominant species, in all filarial indicator areas (68.1, 53.4, 40.8 and 20.8 mosquitoes/room) in Minyat Al-Ashraaf, Kebreet, El-Salmia villages and Fowa city, respectively. $C x$. pipiens was the only species to carry infective larvae as well as other stages, while $C x$. antennatus carried immature stages only (not infective). Filarial larvae in $C x$. pipiens and $C x$. antennatus were found only in Minyat Al-Ashraaf and Kebreet villages. It is inferred from the data that different levels of habitat with regard to rice cultivation have different effects on mosquito diversity and abundance. Also, our study revealed that filarial vectors $C x$. pipiens and $C x$. antennatus had a wide distribution and high relative density especially in irrigated rice regions and hence its role in disease transmission in Kafr El-Sheikh region needs further investigation .
\end{abstract}

Keywords: Mosquito, Abundance, Diversity, Density, Filaria, Kebreet, Minyat Al-Ashraaf, El-Salmia villages and Fowa city.

\section{Introduction:}

In general, mosquitoes stand out most among the numerous species of blood sucking arthropods that annoy human. But what is more important, is their role in transmission of many serious diseases (Morsy et al, 1990). At least 3500 species of mosquitoes are known all over the world and being found in almost every country
(Stone, 1975). Most of these species act as vectors of different pathogens that cause dengue fever, yellow fever, malaria, lymphatic filariasis, Japanese encephalitis or other serious disease of humans (Service 1996). In Egypt, Culex spp. have a wide distribution and are the main vector of Rift valley fever virus (Darwish and Hoogastraal, 1981), Wuchereria bancrofti (Gad et al., 1996) and Western Nile virus 
(Pelah et al., 2002). Bancroftian filariasis is focally endemic in the Nile Delta of Egypt (Harb et al.,1993). The main vector responsible for transmission of filariasis in Egypt is C. pipiens L (Southgate 1979). At present, most endemic villages are characterized by low infection prevalence rates, and low infection intensities (Weil et al.,1999) (Egyptian Ministry of Health and Population, unpublished data).

A basic attribute of mosquito populations is abundance; consequently, its estimation is one of the most important activities of mosquito ecologists. Abundance is a key factor in various types of studies, including life table analyses, assessment of control strategies, and estimation of vectorial capacity.

Irrigated rice agro ecosystems in Africa are associated with a wide spectrum of mosquito fauna. In a study to investigate the succession of mosquito species and their abundance in relation to rice cropping cycles in Bansang, Gambia, 32 mosquito species from seven genera were observed (Snow 1983). In Lower Moshi Tanzania, ten species belonging to the genera Anopheles, Culex and Mansonia coexisted in a rice-village complex (Ijumba et al., 2002). In the Kano Plains, Kenya, indoor and outdoor adult mosquito collections in a rice agro ecosystems yielded a total of 35 species from eight genera (Chandler et al., 1975, Chandler et al., 1976). However, despite the importance of rice cultivation in the proliferation of diverse mosquito species, most research efforts in African rice agro ecosystems have been directed towards An. gambiae and An. funestus (Chandler et al., 1976, Marrama et al., 1995, Ijumba et al., 2002, Ijumba and Lindsay 2001, Briet et al., 2003, Klinkenberg et al., 2003, Mutero et al., 2000, 2004).

Studies across Africa have demonstrated the link between irrigated agriculture and health. Although irrigation may not necessarily increase the prevalence of malaria (Ijumba and Lindsay 2001, Mutero et al., 2004), it has been shown to aggravate the problem of other mosquito borne disease. A study by Hunter et al., (1992) in northeast Ghana revealed that all communities reporting $B$. filariasis as a public health problem were former beneficiaries of irrigated agricultural development. In the Gomoa Okyereko rice agro ecosystem in Ghana, natural infections of B. filariasis were reported in Culex quinquefasciatus and Mansonia species (Mawuli et al, 1999). An increase in soil moisture associated with irrigation development in the southern Nile Delta, following the construction of the Aswan High Dam, caused a rapid rise in the abundance of Cx. quinquefasciatus Say, and consequently, an increase in prevalence of B. filariasis (Thompson et al., 1996). Also in the Nile Delta, Cx. quinquefasciatus females were 3.3 times more likely to be infected in agriculturally - based villages than non-agricultural rural villages (Farid $e t$ al. 2000). Additionally, mosquitoes cause considerable biting annoyance and interfere with both indoor and outdoor activities particularly in irrigated agro ecosystems where they occur in abundance (Lacey and Lacey 1990).

A proper understanding of the relationship between agricultural activity and the occurrence, abundance and distribution of mosquito densities may provide information relevant to the development and implementation of an Integrated Vector Management (IVM) program based on adult productivity and variability. In order to evaluate the relationship between farming practices and mosquito species diversity, the present authors conducted a preliminary entomological study in three villages representing different agro ecosystems (rural areas) and one urban area. The objective of the present work was to provide updated information on the diverse, abundance, distribution, density and identification of mosquitoes fauna associated with rice cultivation in Fowa center, Kafr El-Sheikh Governorate, specially those, which are responsible for filarial transmission. 


\section{Material and Methods:}

\section{Study sites:}

The present study was conducted in

Kebreet, Minyat Al-Ashraaf, El-Salmia villages and Fowa city belonging to Fowa center in Kafr El-Sheikh Governorate. A survey was carried out from June to Oct. 2009 during the rice cultivation season.

This Governorate is one of the most important agricultural provinces on the national level and located in the far north of the Arab Republic of Egypt overlooking the Mediterranean a long a coastline of $100 \mathrm{Km}$ and is bordered to the west of the Rosetta branch a long the $85 \mathrm{Km}$ to its mouth in the Mediterranean sea, in the east Dakahlyia and in the south by Garbeyia. Kafr El-Sheikh is considered as one of the most important province in production of rice $(30 \%$ of the Egyptian production).

\section{Larval survey:}

Collection of larvae was carried out from different breeding places (Sewage wells, Drains, Canals and Rice fields) in all the four indicator areas using a rounded net dipper (17 $\mathrm{Cm}$ in diameter) with a wooden handle (130 $\mathrm{Cm}$ length). Monthly, tow dips were made randomly in each habitat, the contents of the traps were inverted in white enamel pans filled with clean water. The larvae were killed with hot water or formalin and identified according to Gad (1955).

\section{Adult survey:}

Monthly, in each selected area, ten randomly selected houses were sampled for collection of resting mosquitoes between 07:00 - 11:00 p.m. hours by aspirators added by a torch flash light. The aspirated mosquitoes were stored in screened labeled paper cups with cotton wetted with glucose solution (WHO, 1975).

\section{Mosquito identification and dissection:}

Most of the mosquitoes collected were identified morphologically to species using the keys given by kirkpatrick (1925), Gad (1963) and Morsy et al, (1990). The digestive tracts of fed females were dissected, placed in $20 \mu \mathrm{l}$ of distilled water, and teased a part to liberate the stomach contents.

After drying the preparations, were fixed and stained with Giemsa. The microfilarial worms were classified as infected larvae ( $\mathrm{L}_{1}$ sausage stage, $\mathrm{L}_{2}$ motile short) and infective larvae ( $\mathrm{L}_{3}$ motile with caudal papillae) ( Gillies and Coetzee 1987).The micrifilariae in each preparation were counted using a compound microscope at a magnification of X 100 to determine the infection load per mosquito.

Data analysis:

Statistical analysis was done using SPSS software (Version 15.0 for Windows, SPSS Inc., Chicago, 11). Variation in larval densities between habitats (rice field, drains, canals and sewage) was compared by Student $t$ - test . One - way analysis of variance (ANOVA) was used to compare the differences in the number of mosquito larvae in different habitats (three village and city). Relative density was calculated using the number of specimens of each species and the number of all specimens, according to the following formula (Kocatas, 1992): $\mathrm{D}=\mathrm{NA} / \mathrm{N}$ $\mathrm{x} 100$ where $\mathrm{D}$ is relative density, NA is the number of specimens of species $\mathrm{A}$, and $\mathrm{N}$ is the number of all specimens. Shannon diversity index $(H)$ evenness $(E H)$ were done by computer program to characterize species diversity in the four study sites in Fowa center.

\section{Results:}

\section{Larval survey}

Species composition and abundance

The relative abundance of mosquito larvae collected in Kebreet village is given in table (1). A total of 3,339 mosquitoes belonging to four genera and 8 species was caught through the cultivated rice period. The genus Culex was more diverse with four species, followed by Anopheles with two species, Aedes and Culiseta with one species. Among the culicines, $C x$. antennatus was the predominant mosquito species (1091) in all samples followed by $C x$. pipiens (967). Other culicines collected included $C x$. univittatus (481) and $C x$. deserticola (35).The genus Anopheles was mainly dominated by $A n$. pharoensis (523) followed by An. coustani (211). Other species collected were Culiseta sp. (27) and Ae. caspius (4). 
Data in table (2) declare the relative abundance of mosquito larvae collected in Minyat Al-Ashraf village. A total of 3525 mosquito larva belonging to four genera and 8 species were collected during the study period. The genus Culex was more diverse with four species, followed by Anopheles with two species, Aedes and Culiseta with one species. Among the culicines, $C x$. pipiens was the predominant mosquito species $(1,346)$ in all samples followed by $C x$. antennatus (984). Other culicines collected included $C$. univittatus (385) and $C x$. deserticola (21). The genus Anopheles was mainly dominated by An. pharoensis (397), followed by An. coustani (145). Other species collected were Ae. caspius (222) and Culiseta sp.(25).

In El-Salmia village table (3), the relative abundance of mosquito larvae collected belonging to two genera and 6 species was (3331) during the study period. The genus Culex was more diverse with four species, followed by Anopheles with two species. Among the culicines, Cx. pipiens was the predominant mosquito species (1471) in all samples followed by $C x$. antennatus (965), $C x$. univittatus (534) and $C x$. deserticola (28). The genus Anopheles was mainly dominated by An. pharoensis (260), followed by An. coustani (73).

The relative abundance of mosquito larvae collected in Fowa city is shown in table (4). A total of 1186 mosquitoes belonging to two genera and 4 species was caught through the study period. The genus Culex was more diverse with three species, followed by Culiseta with one species. Among the culicines, Cx. pipiens was the predominant mosquito species (680) in all samples followed by Cx. univittatus (398), Cx. antennatus (69) and Culiseta sp.(39).

\section{Species diversity and evenness}

The Shannon diversity index $(H)$ was used to characterize species diversity in the three villages and one city belonging to Fowa center in Kafr El-Sheikh Governorate. The diversity index $(H)$ and evenness $(E H)$ of mosquito species in the (rice cultivated areas); Minyat Al-Ashraf, Kebreet and El-Salmia villages (Shannon diversity Index, $H=1.286$, $E H=0.829 ; H=1.227, E H=0.742 ; H=$ $1.110, E H=0.882$; respectively) were much higher than in the sites with non rice cultivation (Fowa city) $(H=0.718, E H=$ 0.608. This implies that the irrigated agroecosystem has a greater number of species present with the individuals in the community being distributed more equitably among these species (Table 5).

\section{Spatial distribution of mosquitoes}

In Kebreet village, the data showed a significant higher numbers of mosquitoes $(\mathrm{P}<0.01)$ collected from the canals and rice filed with percentages (39.4\%) and (36.2\%), respectively than in either of the other drains (12.9\%) and sewage (11.5\%). On the level of species, the highest percentages of species collected from the rice field were: $A n$. pharoensis (88.5\%), An. coustani $(86.7 \%)$ and $C x$. antennatus $(47.1 \%)$ in comparison with the same species collected from other habitats. Also, C. univittatus (45.9\%), Cx. pipiens (70.9\%), Cx. deserticola (94.3\%), Culiseta sp. (66.7\%) and Ae. caspius (100\%) were higher in the canals than in the other ecosystems.

Data obtained from Minyat Al-Ashraf village recorded that no significant difference was occurred in the total number of mosquito larvae $(\mathrm{P}>0.05)$ between rice filed and canals with percentages (37.4\%) and (37.2\%), respectively, but significantly different with other drains (14.7\%) and sewage (10.7\%). On the level of species, the density of $A n$. pharoensis (89.7\%), An. coustani (91.0\%) and $C x$. antennatus $(49.5 \%)$ were higher in the rice field than in the other habitats. On the other hand, $C x$. univittatus (46.0\%), $C x$. pipiens $(55.6 \%), C x$. deserticola $(100 \%)$ and Culiseta sp.(72.0\%) were higher in the canals than the other ecosystems. A higher density of Ae. caspius (64.4\%) was recorded in the drains than in the other ecosystems.

In El-Salmia village, Data of table (3) showed no significant difference in densities of mosquito larvae $(\mathrm{P}>0.05)$ between rice field $(34.6 \%)$ and canals $(35.1 \%)$, but they were significantly different with other drains $(14.7 \%)$ and sewage $(15.5 \%)$. On the level of species, higher densities of An. pharoensis (95.0\%), An. coustani (100\%) and $C x$. antennatus $(43.6 \%)$ were collected from the rice field than from other habitats. However, $C x$. pipiens $(47.5 \%)$ and $C x$. deserticola $(82.1 \%)$, were higher in the canals than other 
ecosystems. Approximately similar in densities of $C x$. univittatus was apparent among the drains and canals habitats $(42.2 \%$ and $34.8 \%$, respectively). Moreover, Ae. caspius and Culiseta sp. didn't record in this village.

A significant difference in densities of mosquito larvae $(\mathrm{P}<0.001)$ between canals $(66.9 \%)$ and sewage $(33.1 \%)$ were observed in Fowa city. The density of $C x$. univittatus (72.1\%) and $C x$. pipiens $(68.1 \%$ ) were higher in the canals than in the sewage. Also, the density of $C x$. antennatus $(66.7 \%)$ was higher in the sewage in comparison with the canals. Approximately similar densities of Culiseta $s p$ in sewage (46.2\%) and canals (53.8\%) habitat were obtained.

On the other hand, An. pharoensis, An. coustani and Ae. caspius didn't record in sewage habitats in the three villages and the one city studied. Also, Ae. caspius and Culiseta spp. didn't record in rice fields, meanwhile $C x$. deserticola didn't record in rice fields and drains in all villages studied. An. pharoensis, An. coustani, and $C x$. antennatus were more abundant in rice field (three villages) than other habitats. In contrast, $C x$. pipiens and $C x$. univittatus were more abundant in the canals habitat. Overall, the highest number of all mosquito species were recorded in the rice fields and canals in three villages compared with sewages and drains. Also, in Fowa city highest number of all mosquito species were recorded in the canals compared with sewage.

ANOVA showed that, the differences in the numbers of mosquito species was resulted from the significant differences between the sites of collection $(F=3.4, \mathrm{df}=$ $3, P<0.01)$ and also between the mosquitoes species $(F=14.3, \mathrm{df}=7, P<0.001)$. The least significant difference (L.S.D.) revealed that there were no significant differences in the total numbers of mosquito species between the 3 villages but a significant difference was recorded between the 3 villages and Fowa city. However, the L.S.D. for mosquito species exhibited that the highest number of mosquito species was $C x$. pipiens as compared with all species except $C x$. antennatus.

\section{Adult survey}

Data in table (6) showed the population diversity and densities of adult mosquitoes species collected in Kebreet, Minyat AlAshraaf, El-Salmia villages and Fowa city. As shown from the results, the highest diversity and density of adult mosquito species obtained from Minyat Al-Ashraaf were 5 species $(33.8 \%)$, followed by Kebreet 5 species (31.6\%), El-Salmia 4 species (24.5\%), respectively compared with 3 species (10.1\%) in Fowa city. Cx. pipiens adults were the predominant species, in all studied areas ( 68.1, 53.4, 40.8 and 20.8 mosquitoes/room) followed by $C x$. antennatus (16.1, $18.7, \quad 11.9$ and 0.2 mosquitoes/room) in Minyat Al-Ashraaf, Kebreet, El-Salmia villages and Fowa city, respectively. The density was higher in filarious than non filarious areas. The results of larval surveys showed that some species were not discovered in the adult survey.

\section{Prevalence of infection in mosquitoes}

Data recorded in table (7) revealed that, $C x$. pipiens was the only species to carry infective larvae ( $3^{\text {rd }}$ instar larvae of filaria) as well as other stages. $C x$. antennatus carried the immature stages only (not infective larvae), while other mosquito species were found to be negative. Filarial larvae in $C x$. pipiens and $C x$. antennatus were detected only in Minyat Al-Ashraaf and Kebreet villages. The dissection of females showed that $21(2.7 \%)$ out of 780 females were infected in Minyat Al-Ashraaf, while 3 $(0.4 \%)$ out of 756 females were infected in Kebreet village. The percentages of infective mosquitoes were $0.5 \%$ and $0.0 \%$, in Minyat Al-Ashraaf and Kebreet villages, respectively.

\section{Discussion:}

Climatic changes, increases in population movements, and changes in agricultural culture as the result of large-scale irrigation initiated as part of the Southeastern Anatolia Project (abbreviated as GAP in Turkish) are expected to create a considerable increase in mosquito and malaria problems in Southeastern Anatolia (Tabuk and Yildirim, 1999; Ozer et al., 2001). 
In Kafr El-Sheikh Governorate as in the other parts of the Nile Delta, rice is cultivated at the beginning of June and extended till the end of October with irrigation cycles on every 3-5 days during the growing period. So, due to its short lasting period in addition to its irrigation scheme, create a considerable increase in mosquito diversity, abundance and the rate of transmission of mosquitoborne diseases like filariasis.

The present results of mosquito larvae survey showed that, four genera and eight species namely; $C x$. pipiens, $C x$. antennatus, $C x$. univittatus, $C x$. deserticola, An. pharoensis, An. coustani, Ae. caspius, and Culiseta $s p$ were collected in three villages and one city belonging to Fowa center in Kafr El-Sheikh Governorate. The rate of collection increased in rural than in urban areas. No significant differences in the density of mosquito species larvae between the 3 villages (rural areas) but a significant difference was recorded between the 3 villages and Fowa city. Higher collections were found in Minyat Al-Ashraaf followed by Kebreet and El Salmia villages. These are the rural and agricultural areas. Certain farming practices, such a rice-growing, providing a large area of shallow, standing water were the ideal breeding places of mosquitoes. The rate of collection decreased in urban areas with agricultural and manufactures environments like Fowa city. The results agreed with (Farid et al., 2000;El-Bashier et al., 2006 and Muturi et al., 2006).

A significant variation in mosquito density and species richness was observed in the three agroecosystems and Fowa city. These variations may be due to the observed differences in the diversity of aquatic habitats among the three villages and Fowa city. The irrigated agroecosystem had more diverse habitat types, thereby supporting diverse mosquito species. The Culex mosquitoes breed in a wide range of habitats although they have been able to exploit same habitats as Anopheles mosquitoes (Mwangangi et al., 2009). Previous studies have reported a positive relationship between habitat type diversity and mosquito species richness (Kenawy and El-Said 1989; Ijumba et al., 2002; Shililu et al., 2003).

Larvae of $C x$. pipiens were found in all villages and Fowa city without marked difference in density. Cx. antennatus was found in all indicator areas but with very much lower in Fowa city. This is probably due to absence of rice fields there, its favorable breeding places. $C x$. univittatus was found in all studied areas but with much higher in Fowa city. An. pharoensis and An. coustani were found in all villages but $A n$. pharoensis and An. coustani not detected in Fowa city, this is probably due to absence of rice fields there, its favorable breeding places. Ae. caspius, Culiseta sp and $C x$. deserticola were found in few numbers in all indicator areas. In rice agroecosystems, irrigated rice fields and associated habitats such as irrigation channels areas are the principal mosquito larval habitats (Snow, 1983, Mutero et al., 2000, Ijumba et al.,2002) and continue to support mosquito populations during the dry season when the other larval habitats are dry.

The most abundant types were: $C x$. pipiens, Cx. antennatus, Cx. univittatus, An. pharoensis and An. coustani. C. pipiens and $C x$. antennatus were found in all types of breeding places, especially canals and rice field, meanwhile the least favorable places was sewage and drains, respectively. This curious preference of $C x$. pipiens and $C x$. antennatus explains their wide prevalence. Rifaat et al., (1970) in Sharkia reported that Cx. pipiens represented $83.4 \%$ of all larvae collected thought the year and the larvae prefer wells and cesspits, while rice fields were abundant. Mohamed et al., (1981) in Giza found that $C x$. pipiens was the most common mosquito species forming 97.95 of all species and the larvae found in all breeding places especially in cesspits, canals, drains, seepage and lastly wells. Kenawy and El Said (1990) reported that the rice is of significant preference for breeding of culicine 
Mosquito species.....

larvae mainly $C x$. antennatus. Morsy et al., (1990) found $C x$. pipiens and $C x$. antennatus 
larvae the most common species in Nile valley, Oases and Suez canal zone. El Shazly et al., (1998) in Mansoura found that the most abundant types were $C x$. univittatus, $C x$. antennatus and Ae. caspius, while the least common types were $C x$. deserticola and neither detected $C x$. pipiens in drains, sewage wells nor rice fields. Only a small percent was in a canal of Mansoura center, also, $C x$. antennatus found only in rice field. Mostafa et al., (2002) over three years study found that $C x$. pipiens and $C x$. antennatus were the main species in four Egyptian governorates.

The present study revealed that, $A n$. pharoensis and An. coustani were more abundant in rice field (three villages) than other habitats. Mosquito species that utilize rice fields as breeding sites were found in significantly higher densities in rice agroecosystems. For instance An. gambiae, An. pharoensis, An. sinensis and $C x$. quinquefasciatus which are important Riceland mosquitoes ( Kaschef et al., 1982, Lacey and Lacey, 1990, Kenawy et al., 1998, Mutero et al., 2000, Shin et al., 2004) were captured in significantly higher densities in rice agroecosystems than in the non-irrigated agroecosystem. Cross-correlation analysis further confirmed that mosquito production in the rice agroecosystems was least dependent upon rainfall, an indication that it is most likely influenced by rice cultivation (Mutero et al., 2004). An. pharoensis is exceptional as it prefers rice field habitat for breeding $(\mathrm{Gad}$ et al., 1982), the association of An. pharoensis with rice plantation has been fully documented (Kirkpatrick, 1925; Halawani and Shawarby, 1957 and Zahar, 1974) and the influence of such association on species distribution in Egypt was discussed in details by Kenawy and El-Said (1990). Lacey and Lacey (1990) observed that the source and clarity of water play a marked role in the presence and abundance of the rice field mosquitoes. In addition, Meisch et al., (1982) reported that the only significant correlation of a mosquito species with changes in environmental factors of rice field water was the depth.

The least common species were: $A e$. caspius, Culiseta sp and Cx. deserticola. Ae. caspius detected in canals and drains and there is no larvae detected in sewage wells and rice fields in the different localities. This is in accordance with Kirkpartick (1925) who found that these species were abundant only in the Nile Delta, and Salem (1933) who found them around Cairo and Oases. Wassif (1969) found these species in great numbers along the costal area. Hurlbut and Weitz (1956) found them among the commonest five mosquitoes of Nile Delta perhaps the discrepancy in the density comes from the fact that the species prefers to have shelters outside human habitations. El Shazly et al., (1998) gave the same observation. Also, Culiseta $s p$. was recorded in canals, drains and sewage wells and not detected in rice field in the different areas, this differs from that of Kikpatrick (1625) who found it throughout the Nile Valley and Salem (1933) who found it in the Oases, but it agreed with Gad (1956) and Morsy et al., (1990) who found it in the Suez canal zone, around Cairo, in Faiyum, in Northern Delta and in some Oases. Moreover, Cx. deserticola was found only in few numbers in canals and sewage wells, the results agreed with those published by El Shazly et al., (1998).

The highest diversity and density of adult mosquito species were obtained from three villages compared with Fowa city. $C x$. pipiens adults were the predominant species, in all studied areas $(68.1,53.4,40.8$ and 20.8 mosquitoes/room) followed by $C x$. antennatus (16.1, 18.7, 11.9 and 0.2 mosquitoes/room) in Minyat Al-Ashraaf, Kebreet, El-Salmia villages and Fowa city, respectively. The density was higher in filarious than non filarious areas and the difference was statistically significant. This agreed with (Chandler et al., 1975; Kaschef et al., 1982).

Cx. pipiens was the only species found to carry infective larvae as well as other 
stages. Cx. antennatus carried the immature stages only (not infective larvae), while other mosquito species were found to be negative. The present results agreed with Kaschef et al., (1982). Filarial larvae in $C x$. pipiens and $C x$. antennatus were detected only in Minyat AlAshraaf and Kebreet villages and not found in Fowa city. Culex spp. have a wide distribution and are the main vector of $W$. bancrofti (Gad et al., 1996). In the Nile Delta of Egypt, $C x$. pipiens females were 3.3 times more likely to be infected in agriculturally based villages than non-agricultural rural villages (Farid et al. 2000). The percentage of infected and infective mosquitoes (2.7 and $0.5 \%$ respectively) is lower than that found by Wassif (1969) in Meet Ghamr (9.14 and $1.14 \%$, respectively) and Kaschef et al., (1982) in Abu Hammad (4.6 and 0.8

respectively). This may be ascribed to the effect of insecticides on filarial larvae in mosquitoes and the treatment programme of filariasis in Kafer El-Sheikh Governorate. Mohamed et al., (1981), found that the percentage of infected and infective mosquito were 0.58 and $0.07 \%$ in Giza governorate. Khalil et al., (1932) reported that wild-caught $C x$. pipiens harbored infective larvae of $W$. bancrofti, the agent of human B. filariasis. In the laboratory, Riffat et al., (1970) obtained infective larvae from laboratory reared female $C x$. pipiens fed on a filariasis patient. $C x$. antennatus and $C x$. univittatus were also found to be naturally infected with $W$. bancrofti larvae and to support the development of these larvae to the infective stage after feeding on an infected patient (Riffat et al., 1969;1970).

\section{Conclusion:}

It is inferred from the data that different levels of habitats with regard to rice cultivation have different effects on mosquito diversity and abundance. Also, the present study revealed that filarial vectors $C x$. pipiens and $C x$. antennatus had a wide distribution and high relative density especially in irrigated rice regions and hence its role in disease transmission in Kafr El-Sheikh region needs further investigation. This makes it necessary to have further investigations on the biology and ecology of mosquito breeding in the rice fields. This is of importance for planning of a control strategy mainly through culture practices. 
Table (1): Relative abundance of mosquito larvae collected from different habitat in Kebreet village during the period from June to October 2009.

\begin{tabular}{ccccccccc|cc}
\hline $\begin{array}{c}\text { Mosquitoes } \\
\text { species }\end{array}$ & \multicolumn{2}{c}{ Rice field } & \multicolumn{2}{c}{ Drains } & \multicolumn{2}{c}{ Canals } & \multicolumn{2}{c|}{ Sewage wells } & \multicolumn{2}{c}{ Total collected } \\
larvae
\end{tabular}

The total number followed by the same letter are not significantly different $(\mathrm{P}>0.05)$.

Table (2): Relative abundance of mosquito larvae collected from different habitat in Minyat AlAshraf during the period from June to October 2009.

\begin{tabular}{ccccccccc|cc}
\hline $\begin{array}{c}\text { Mosquitoes } \\
\text { species }\end{array}$ & \multicolumn{2}{c}{ Rice field } & \multicolumn{2}{c}{ Drains } & \multicolumn{2}{c}{ Canals } & \multicolumn{2}{c}{ Sewage wells } & \multicolumn{3}{c}{ Total collected } \\
larvae
\end{tabular}

The total number followed by the same letter are not significantly different $(\mathrm{P}>0.05)$. 
Table (3): Relative abundance of mosquito larvae collected from different habitat in El-Salmia during the period from June to October 2009.

\begin{tabular}{ccccccccc|cc}
\hline $\begin{array}{c}\text { Mosquitoes } \\
\text { species }\end{array}$ & \multicolumn{2}{c}{ Rice field } & \multicolumn{2}{c}{ Drains } & \multicolumn{2}{c}{ Canals } & \multicolumn{2}{c|}{ Sewage wells } & \multicolumn{2}{c}{ Total collected } \\
larvae
\end{tabular}

The total number followed by the same letter are not significantly different $(\mathrm{P}>0.05)$.

Table (4): Relative abundance of mosquito larvae collected from different habitat in Fowa city during the period from June to Oct 2009.

\begin{tabular}{ccccc|cc}
\hline Mosquitoes species & \multicolumn{2}{c}{ Canals } & \multicolumn{2}{c|}{ Sewage wells } & \multicolumn{2}{c}{ Total collected } \\
& No. & $\%$ & No. & $\%$ & No. & $\%$ \\
\hline Cx. antennatus & 23 & 33.3 & 46 & 66.7 & 69 & 5.8 \\
Cx. univittatus & 287 & 72.1 & 111 & 27.9 & 398 & 33.6 \\
Cx. deserticola & 0.0 & 0.0 & 0.0 & 0.0 & 0.0 & 0.0 \\
$\begin{array}{c}\text { Cx. pipiens } \\
\text { Culiseta sp. }\end{array}$ & 463 & 68.1 & 217 & 31.9 & 680 & 57.3 \\
Ae. caspius & 0.0 & 0.0 & 0.0 & 0.0 & 0.0 & 0.0 \\
An. coustani & 0.0 & 0.0 & 0.0 & 0.0 & 0.0 & 0.0 \\
An. pharoensis & 0.0 & 0.0 & 0.0 & 0.0 & 0.0 & 0.0 \\
\hline Total & $794^{\mathrm{a}}$ & 66.9 & $392^{\mathrm{b}}$ & 33.1 & \multicolumn{2}{c}{1186} \\
\hline
\end{tabular}

The total number followed by the same letter are not significantly different $(\mathrm{P}>0.05)$. 
Table(5): Species diversity and evenness in three villages and one city in Khafr El-Sheikh Governorate, Egypt during the period from June to October 2009.

\begin{tabular}{|c|c|c|}
\hline Sites & $\begin{array}{c}\text { Shannon's Diversity } \\
\text { Index }(\boldsymbol{H})\end{array}$ & $\begin{array}{c}\text { Shannon's Equitability } \\
(\boldsymbol{E} \boldsymbol{H})\end{array}$ \\
\hline Kebreet & 1.227 & 0.742 \\
\hline Minyat Al-Ashraf & 1.286 & 0.829 \\
\hline El-Salmia & 1.110 & 0.882 \\
\hline Fowa city & 0.718 & 0.608 \\
\hline
\end{tabular}

Table (6): Relative abundance of adult mosquitoes Species collected indoor from three villages and one city in Khafr El-Sheikh Governorate, Egypt during the period from June to October 2009.

\begin{tabular}{|c|c|c|c|c|c|c|}
\hline Locality & $\begin{array}{c}\text { No. of room } \\
\text { examined }\end{array}$ & Species & $\begin{array}{l}\text { No. of } \\
\text { males }\end{array}$ & $\begin{array}{c}\text { No. of } \\
\text { females }\end{array}$ & $\begin{array}{c}\text { Total } \\
\text { number }(\%)\end{array}$ & $\begin{array}{l}\text { Density per } \\
\text { room }\end{array}$ \\
\hline \multirow{5}{*}{ Kebreet } & \multirow{5}{*}{18} & Cx. pipiens & 163 & 798 & 961 (66.6) & 53.4 \\
\hline & & Cx. antennatus & 76 & 261 & $337(23.3)$ & 18.7 \\
\hline & & Cx. univittatus & 13 & 44 & $57(3.9)$ & 3.2 \\
\hline & & An.pharoensis & 7 & 71 & $78(5.4)$ & 4.3 \\
\hline & & An. coustani & - & 11 & $11(0.8)$ & 0.6 \\
\hline \multirow[t]{2}{*}{ Total } & - & $5 \mathrm{sp}$. & 259 & 1185 & $1444(31.6)$ & 80.6 \\
\hline & \multirow{5}{*}{18} & Cx.pipiens & 185 & 1041 & $1226(79.4)$ & 68.1 \\
\hline \multirow{4}{*}{$\begin{array}{c}\text { Minyat Al- } \\
\text { Ashraf }\end{array}$} & & Cx. antennatus & 61 & 229 & $290(18.8)$ & 16.1 \\
\hline & & Cx. univittatus & - & 14 & $14(0.9)$ & 0.8 \\
\hline & & An. pharoensis & - & 7 & $7(0.5)$ & 0.4 \\
\hline & & An. coustani & - & 8 & $8(0.5)$ & 0.4 \\
\hline Total & - & $5 \mathrm{sp}$. & 246 & 1299 & $1545(33.8)$ & 85.8 \\
\hline \multirow{4}{*}{ El-Salmia } & \multirow{4}{*}{20} & Cx.pipiens & 44 & 772 & $816(72.9)$ & 40.8 \\
\hline & & Cx. antennatus & 41 & 197 & $238(21.2)$ & 11.9 \\
\hline & & Cx. univittatus & 1 & 34 & $35(3.1)$ & 1.8 \\
\hline & & An.pharoensis & 3 & 26 & $29(2.6)$ & 1.5 \\
\hline \multirow[t]{2}{*}{ Total } & - & $4 \mathrm{sp}$. & 89 & 1029 & $1118(24.5)$ & 55.9 \\
\hline & & Cx.pipiens & 45 & 351 & $396(86.1)$ & 20.8 \\
\hline \multirow[t]{2}{*}{ Fowa city } & 19 & Cx. antennatus & - & 3 & $3(0.7)$ & 0.2 \\
\hline & & Cx. univittatus & 4 & 57 & $61(13.3)$ & 3.2 \\
\hline Total & - & 3 sp. & 49 & 411 & $460(10.1)$ & 24.2 \\
\hline
\end{tabular}


Table (7): Filarial infection and infective rates of mosquito species in three villages and one city in Khafr El-Sheikh Governorate, Egypt during the period from June to October 2009.

\begin{tabular}{ccccccc}
\hline Villages & $\begin{array}{c}\text { No. of } \\
\text { females } \\
\text { dissected }\end{array}$ & $\begin{array}{c}\text { No. of } \\
\text { infected } \\
\text { females } \\
(\%)\end{array}$ & $\begin{array}{c}\text { No. of } \\
\text { infective } \\
\text { females (\%) }\end{array}$ & $\begin{array}{c}\text { Total No. of } \\
\text { filarial larvae } \\
\text { observed }\end{array}$ & $\begin{array}{c}\text { Average No. of } \\
\text { larvae per } \\
\text { infected } \\
\text { mosquito }\end{array}$ & $\begin{array}{c}\text { Range of } \\
\text { larvae per } \\
\text { infected } \\
\text { mosquito }\end{array}$ \\
\hline $\begin{array}{c}\text { Kebreet } \\
\text { Minyat Al-Ashraf }\end{array}$ & 756 & $3.0(0.4)$ & 0.0 & 4 & 1.3 & $1-2$ \\
El-Salmia & 780 & $21(2.7)$ & $4(0.5)$ & 47 & 1.9 & $1-3$ \\
Fowa city & 763 & 0.0 & 0.0 & 0.0 & 0.0 & 0.0 \\
\hline
\end{tabular}

\section{References:}

Briet, J.; J. Dossou-Yovo; E. Akodo; N. Van de Giesen; and M. Teucher; 2003: The relationship between Anopheles gambiae density and rice cultivation in the savannah and forest zone of Cote d'Ivoire. Trop. Med. Int. Hlth. 8: 439-448.

Chandler, J.; R. Highton, and M. Hill.; 1975: Mosquitoes of the Kano plain, Kenya 1. Results of indoor collections in irrigated and non-irrigated areas using human bait and light traps. J. Med. Entomol. 12: 504-510.

Chandler, J.; R. Highton; and M. Hill.; 1976: Mosquitoes of the Kano Plain, Kenya. II. Results of outdoor collections in irrigated and nonirrigated areas using human and animal bait and light traps. J. Med. Entomol. 13: 202- 207.

Darwish, M.; Hoogstraal, H.; 1981: Arboviruses infesting human and lower animals in Egypt: A review of thirty years of research. J. Egypt. Pub. Hlth. Assoc., 56:100-112.

El-Bashier Z.M.; Hassan M.I.; Mangoud A.M.; Morsy T.A. and Mohammad K.A.; 2006: A preliminary pilot survey (Culex pipiens), Sharkia governorate, Egypt., J. Egypt. Soc. Parasitol. 36 (1): 81-92.

El-Shazly, A.M.; Ali, M.E.; Handoussa, A.E. and Abdalla, K.F.; 1998: Studies on culicini larvae in Mansoura center, Dakahlia governorate, Egypt., J. Egypt Soc. Parasitol. 28 (3) :839-847.

Farid, H.; Z. Morsy; A. Hassan; R. Hammad; R. Faris; A. Kandil; E. Ahmed, and G. Weil.;
2000: The impact of environmental and entomological factors on intervillage filarial

focality in the Nile Delta. J. Egypt. Soc. Parasitol. 30: 469-485.

Gad, A.M.; 1955: Distribution of mosquitoes in Egypt. Cited from Wassif, S.F. (1969).

Gad, A.M.; 1956: Mosquitoes of the Oases of the Libyan Desert of Egypt, Bull. Soc. Entomol. d'Egypt. 40: 131-139.

Gad, A.M.; 1963: Insects of medical importance Med. Entom.. Res. Inst. MOH, Dokki.

Gad, A.M.; Kenawy M.A.; El-Said, S. and Merdan, A.; 1982: Field studies on Anopheline mosquito larvae in Egypt (Diptera: Culicidae). 1. Different types and characteristics of the breeding places in relation of the abundance of Anopheline species in Egypt. J. Egypt. Pub. Hlth. Ass., 57: 541-561.

Gad, A.M.; Hammad, R.; Farid, H.A.; 1996: Uptake and development of Wucheria bancrofti in C. pipiens L. and Ae. caspius Pallas. J. Egypt. Soc. Parasitol., 26(2):305-314.

Gillies M.T. and Coetzee M.; 1987: A supplement to anophelinae of Africa south of Sahara (Afro-tropical region), Publication of the South Africa Institute of Medical Research, 55: 1 -143 .

Halawani, A. and Shawarby, A.A.; 1957: Malaria in Egypt. J. Egypt. Med. Ass., 40: 753792. 
Harb, M; Faris, R; Gad, A. M.; Hafez, O.N.; Ramzy, R.M., Buck, A.A.; 1993: The resurgence of lymphatic filariasis in the Nile Delta. Bull World Health Organ 71: 49-54.

Hunter, J.; 1992: Elephantiasis: a disease of development in north-east Ghana. Social Sci. Med. 35: 627-649.

Hurlbut, H.S. and Weitz, B.; 1956: Some observation on the bionomics of the common mosquitoes of the Nile Delta. Amer. J. Trop. Med. Hyg., 5: 901-908.

Ijumba, J. and S. Lindsay; 2001: Impact of irrigation on malaria in Africa: paddies paradox. Med. Vet. Entomol. 15: 1-11.

Ijumba, J.; F. Mosha, and S.W. Lindsay; 2002: Malaria transmission risk variations derived from different agricultural practices in an irrigated area of northern Tanzania. Med. Vet. Entomol. 16: 2838.

Kaschef, A.H.; Mohamed, N.H. and Rashed, S.S.; 1982: Culicid-species in Sharkia governorate. J. Egypt Soc. Parasitol., 12 (1) :115124.

Kenawy M.A. and El-Said, S.; 1989: Characterization of Culicine mosquito habitats in the Nile Delta, Egypt. Proc. Int. Conf. St. Comp. Sc. Soc. Res. and Dem. 1: 211-231.

Kenawy M.A. and El-Said, S.; 1990: Factors affecting breeding of Culicine mosquitoes and their associations in the canal Zone, Egypt. Proc. Int. Conf. St. Comp. Sc. Soc. Res. Demog., 1: 215-233.

Kenawy M.A.; Rashed S.S. and Teleb S.S.; 1998: Characterization of rice field mosquito habitats in Sharkia governorate, Egypt., J. Egypt Soc. Parasitol., 28 (2) :449-459.

Klinkenberg, E.; W. Takken; F. Huibers; and Y. Toure; 2003: The phenology of malaria mosquitoes in irrigated rice fields in Mali. Acta Trop. 85: 71-82.

Kocatas, A.; 1992: Ekoloji-Cevre Biyolojisi, Ege Oniversitesi Matbaasi, Izmir.

Khalil, M.; Malawani, A. and Hilmi, I.S. (1930): The transmission of Bancroftian filariasis in Egypt. J. Egypt. Med. Assoc., 15: 315 - 332.

Kirkpatrick, T.W.; 1925: The mosquitoes of Egypt. The Egyptian Government Press, Cairo.
Lacey, L. and C. Lacey; 1990: The medical importance of riceland mosquitoes and their control using alternatives to chemical insecticides. J. Am. Mosq. Contr. Assoc. 6: 3-93.

Marrama, L.; E. Rajaonarivelo; S. Laventure, and P. Rabarison; 1995: Anopheles funestus et la riziculture sur les plateaux de Madagascar. Cah. Sante. 5: 415-419.

Mawuli, D.; S. K. Dunyo; C. K. Ahorlu; W. Z. Coker; M. A. Appawu; E. M. Pedersen, and P. E. Simonsen; 1999: Bancroftian filariasis in an irrigated project community in southern Ghana. Trop. Med. Int. Hlth. 4: 13-18.

Meish, M.V.; Anerson, A.L.; Watson, R.I. and Olson, L.; 1982: Mosquito species inhabiting rice fields in five rice growing regions of Arkansas. Mosq. News, 42: 341-346.

Mohamed, N.H.; Salem, S.A.; Abdel Baki, M.H. and Fawzy, A.F.A.; 1981: Types of mosquitoes in Giza governorate in reference to filarial., J. Egypt Soc. Parasitol. 28 (2) :449-459.

Morsy, T.A.; El Okbi, L.M.A.; Kamal, A.M.; Ahmed, M.M.; Bo-shra, E.F.; 1990: Mosquitoes of the genus Culex in the Suez Canal governorate, Egypt. J. Egypt. Soc. Parasitol., 11 (2):441-451.

Mostafa, A.A.; Allam, K.A.M. and Osman, M.Z.; 2002: Mosquito species and their densities in some Egyptian governorate. J. Egypt Soc. Parasitol. 32 (1) : 9-20.

Mutero, C.; H. Blank; F. Konradsen and W. Van Der Hoek; 2000: Water management for controlling the breeding of Anopheles mosquitoes in rice irrigation schemes in Kenya. Acta Trop. 76: 253-263.

Mutero, C.; C. Kabutha; V. Kimani; L. Kabuage; G. Gitau; J. Ssennyonga; J. Githure; L. Muthami; A. Kaida; L. Musyoka; E. Kiarie; and M. Oganda; 2004: A transdisciplinary perspective on the links between malaria and agroecosystems in Kenya. Acta Trop. 89: 171186.

Muturi E.J.; Shililu J.; Jacob B.; Gu. W.; Githure J. and Novak R.; 2006: Mosquito species diversity and abundance in relation to land use in a Riceland agroecosystem in Mwea, Kenya., J. Vector Eco., 31 (1): 129-137. 
Mwangangi, J.M.; Muturi E.J. and Mbogo, C.M.; 2009: Seasonal mosquito larval abundance and composition in Kibwezi, lower eastern Kenya. J. Vector Borne Dis. 46: 65-71.

Ozer, N.; Alten, B. and Caglar, S.S.; 2001: Distribution of malaria vectors in Turkey. In: Proceedings of the $1^{\text {st }}$ Balkan Conference Malaria and Mosquito Control, (Ed. A.S. Voyuglou), Greece, pp. 56-61.

Pelah, D.; Abramovich, Z.; Mar-kus, A.; Wiesman, Z.; 2002: The use of commercial saponin from Quillaje saponaria bark as a natural larvicidal agent against Aedes aegypti and $C$. pipiens. J. Ethnopha-rmacol., 81(3):407-409.

Rifaat, M.A.; Mahdi, A.H.; Wassif, S.F. and Talib, M.I.A.; 1969: Certain studies on $C$. univittatus in relation to filariasis in the Nile Delta, U.AR. J. Egypt. Publ. Hlth. Ass., 44: 43-46.

Rifaat, M.A.; Mahdi, A.H. and Wassif, S.F.; 1970: Some ecological studies on Aedes (Ochlerotatus) caspius in the Nile Delta., J. Egypt Pub. Hlth. Ass., 45 (6): 451-457.

Salem, H.M.; 1933: New records of some Egyptian mosquitoes. Bull. Soc. Entom. d' Egypt, 17: 83-90.

Service, M.W.; 1996: Medical Entomology for Students, Cambridge, Cambridge University Press. U.K.

Shililu, J.; G. Tewolde; S. Fessahaye; S. Mengistu; H. Fekadu; Z. Mehari; G. Asmelash; D. Sintasath; G. Bretas; C. Mbogo; J. Githure; E. Brantly; R. Novak, and J. Beier; 2003: Larval habitat diversity and ecology of anopheline larvae in Eritrea. J. Med. Entomol. 40: 921-929.

Shin, E-H; Lee, W-J; Lee, H.I.; Lee, D-K and Klein, T.A.; 2004: Seasonal population density and daily survival of anopheline mosquitoes

(Diptera: Culicidae) in a malaria endemic area, Republic of Korea. J. Vector Eco., 30 (1): 33-40.
Snow, W.; 1983: Mosquito production and species succession from an area of irrigated rice fields in The Gambia, West Africa. J. Trop. Med. Hyg. 86: 237-245.

Southgate, B.A.; 1979: Bancroftian filariasis in Egypt. Trop. Dis. Bull., 76: 1045:1068.

Stone, A.; 1975: A synoptic catalog of the mosquitoes of the world. Supp 3. American Entomology Society Washington DC.

Tabuk, T.C. and Yildirim, C.; 1999: Turkiyede sitma ve sitmada saha Calismalari. In: SitmaMalaria (ed. M.A. Ozcel), Ege Universitesi Basimevi, lzmir, pp. 275-290.

Thompson, D.; J. Malone; M. Harb; R. Faris; O. Huh; and A. Buck; 1996: Bancroftian filariasis distribution and diurnal temperature differences in the southern Nile delta. Emerg. Infect. Dis. 2: 234-235.

Wassif, S.F.; 1969: Survey of the Egyptian culicines in the Nile Delta with special reference to filarial transmission. M.D. Thesis, Faculty of medicine, Ain Shams University.

Weil, G.J.; Ramzy, R.M.R.; El Setouhy, M.; Kandil, A.M.; Ahmed, E.S.; Faris, R.; 1999: A longitudinal study of Bancroftian filariasis in the Nile Delta of Egypt: baseline data and one-year follow-up. Am J Trop Med Hyg 61: 53-58.

World Health Organization; 1975: Manual on practical entomology in malaria, Part II. Methods and techniques, World Health Organization, Geneva.

Zahar, A.R.; 1974: Review of the ecology of malaria vectors in the Eastern Mediterranean Region. Bull. W.H.O., 50: 427-440. 


\section{الملخص العربي}

\section{Please put paper's title and doctor's names here in Arabic like English}

تم في هذه الدر اسة حصر أنو اع البعوض وكذلك معرفة وفرة و كثافة البعوض فى منطقتين مختلفتين

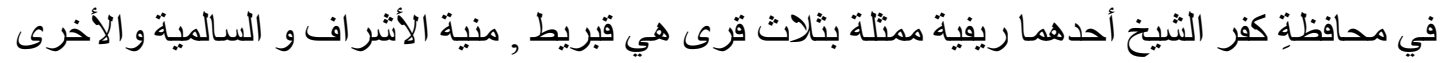

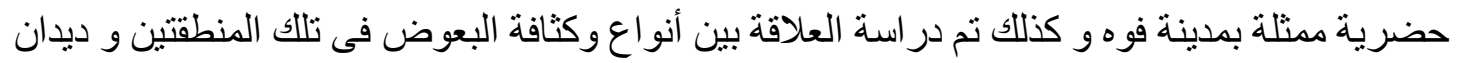

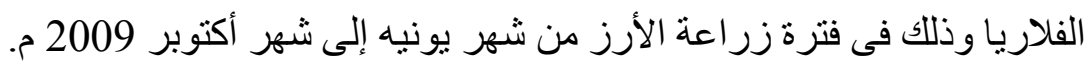

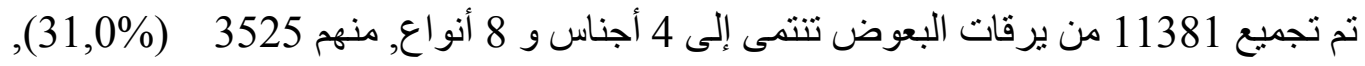

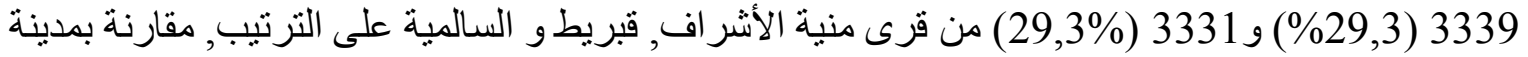

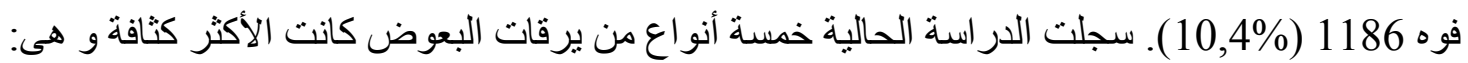

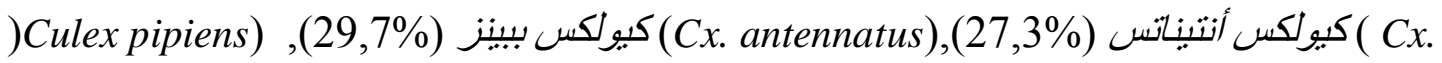

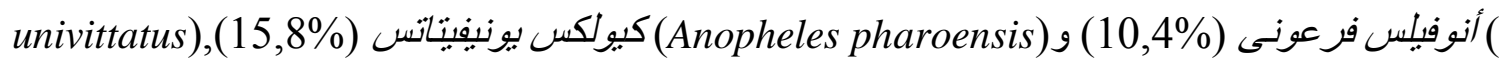

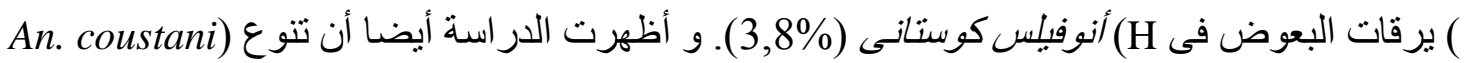

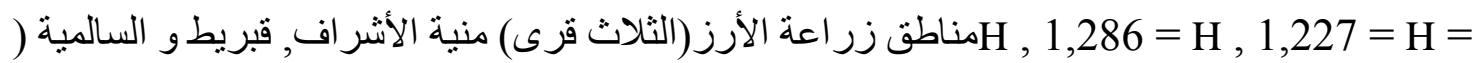

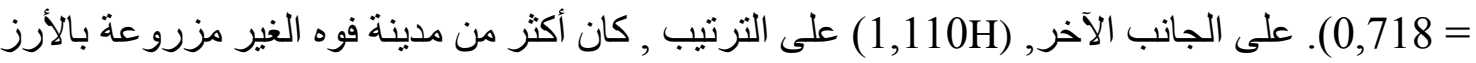

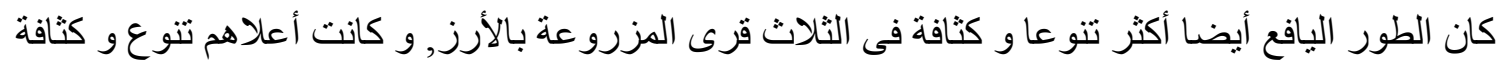

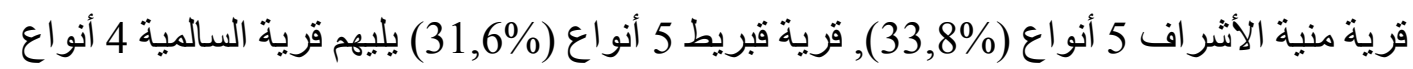
(

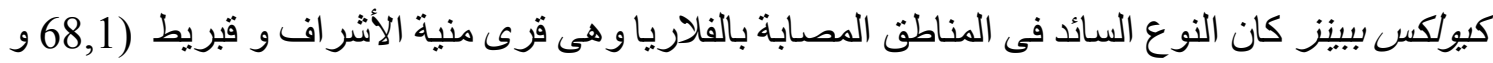

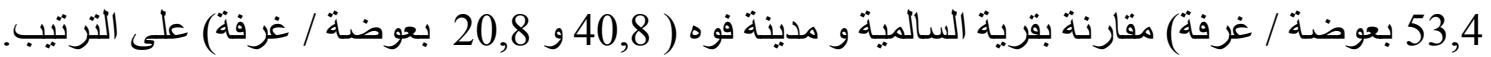

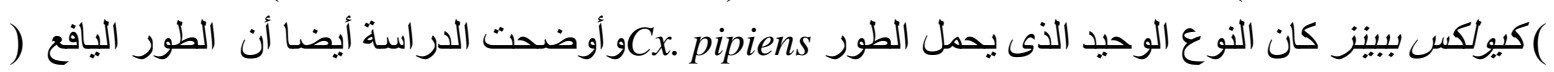

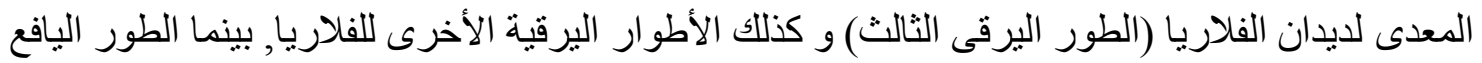

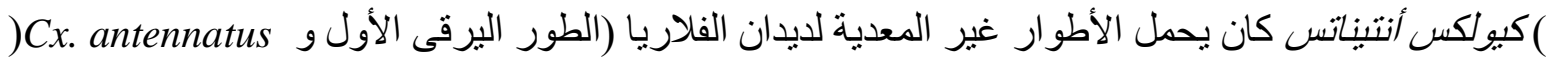

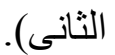

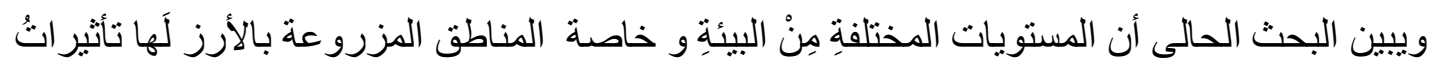

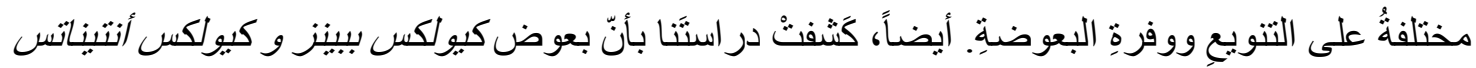

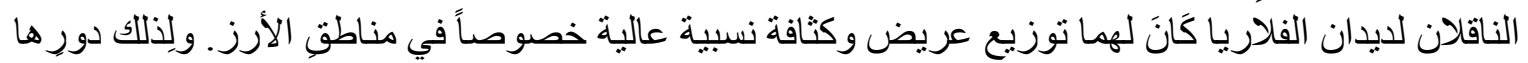
في نقل المرض في كفر الثيخ تحتاج إلى أبحاث و در اسات مستقبلية. 